\title{
A Message from a Bohemian
}

\section{“Interculture": Patočka’s Translation}

\section{of Durych's Boží duha}

\section{Rajendra Chitnis}

\begin{abstract}
Jan Patočka's essay accompanying his 1975 German translation of Jaroslav Durych's novel, Boži duha (God's rainbow, 1969) has divided Czech critics. While some reject altogether his association of the novel with the post-war expulsion of the Bohemian German population from Czechoslovakia, others criticize the effect his essay has had in reducing the novel to this context, undermining its more universal message of reconciliation, and others objected to the co-opting of the conservative Roman Catholic Durych into a secular liberal agenda. This article approaches the translation venture and its reception as a case study in translation history, in order to assess these criticisms in the light of a more accurate and detailed understanding of Patočka's motives for publishing the translation. It focuses on both Patočka and his collaborator in the venture, the German academic, Frank Boldt, and compares his foreword with contemporaneous essays on Comenius and on Czech history. It argues that the real difficulty is not so much Patočka's interpretation of Durych's novel as their long-standing inseparability in translations and Czech editions, which disrupts the careful balance in the novel between history and universality and between didacticism and aestheticism.
\end{abstract}

\section{AbstrakT}

\section{Poselství z české „mezikultury“: Patočkův překlad Durychovy Boží duhy}

Patočkův esej, doprovázejícíjeho německý překlad Durychova románu Božíduha (česky, 1969) z roku 1975, rozděluje české kritiky. Zatímco někteří zcela odmítají jeho spojení románu s poválečným

1) My thanks to Jonathan Bolton, Robert Pynsent and Peter Zusi for their valuable comments on an earlier draft of this article. 
vyhnáním německého obyvatelstva z Československa, jiní kritizují to, že v eseji je román redukován do jednoho historického kontextu a ztrácí se v něm Durychovo obecnější volání po smíření. Jiní zase protestují proti začlenění konzervativního katolíka Durycha do sekulární liberální agendy. V tomto příspěvku přistupuji k Patočkovu překladatelskému projektu a jeho recepci metodou překladatelské historie a posuzuji kritické postoje ve světle přesnějšího a podrobnějšího pojetí $\mathrm{Pa}$ točkových motivací při vydávání tohoto překladu. Sleduji jak Patočku, tak i jeho spolupracovníka v projektu, německého historika Franka Boldta, a srovnávám Patočkovu předmluvu s jeho eseji o Komenském a českých dějinách psanými ve stejném období. Argumentuji, že skutečným problémem není tolik Patočkova interpretace Durychova románu, jako jejich dlouhodobá neoddělitelnost v překladech a českých edicích románu, která ruší křehkou rovnováhu v románu mezi historičností, univerzalitou, didaktismem a estetismem.

\section{KEYWORDS}

Jan Patočka, Jaroslav Durych, translation history, translator intercultures, Czech-German relations.

\section{KLÍČOVÁ SLOVA}

Jan Patočka, Jaroslav Durych, historie překladu, interkultura překladatele, česko-německé vztahy.

Václav Durych, the son of the major twentieth-century Czech writer, Jaroslav Durych (1886-1962), claims with a certain satisfaction that Jan Patočka's 1975 German translation of Durych's novel Boží duha (God's rainbow, 1969) met with exactly the reception from German readers that his father had apparently predicted: for the most part they were not interested, or they were disgusted and did not understand it (DURYCH VÁCLAV 1991: 5, VOJTÍŠKOVÁ-DURYCH 1995: 15). ${ }^{2}$ By contrast, when Patočka's foreword to the German translation was translated into $C z e c h$ as an afterword to the second Czech edition of the novel in 1992, it polarized Czech critics, with several objecting to the political and philosophical interpretations Patočka had imposed on the novel. While Czech commentators have focused on the merits and legitimacy of these interpretations, they have tended to assume - whatever their stance - that Patočka's motives are well understood, when in fact there has been no substantial attempt to reconstruct or make sense of them. This article, by contrast, approaches the project and its reception as a case study in translation history. Patočka's venture

2) Durych's opinion was coloured by the failure of the 1933 German translation of his major historical novel Bloudění (Astray, 1929, translated into English in 1934 as The Descent of the Idol), by Pavel/Paul Eisner (1889-1958). The history of this translation, which had comparable motivations to Patočka's, has been explored in detail by Tilman Kasten (KASTEN 2014). 
demonstrates how much literary translations, especially from less frequently translated literatures, owe their existence to extra-literary rather than aesthetic factors. Its history also highlights how such translations often respond to a particular moment and are framed for a particular audience at a particular point in time, and the extra-literary frame may subsequently prove controversial or irrelevant to another audience at another time. Understanding Patočka's motives more accurately will help show how far his framing of Durych's text genuinely distorts its message, how long and in what contexts he expected the frame to accompany the text, and at what point the frame is no longer needed.

\section{Translator "Intercultures"}

In his work on translation history methodology, Anthony Pym seeks to shift translation history away from text-, data- and system-led approaches towards a focus on the people involved:

There seems little reason why translation history should deploy intricate textual criticism when it could attain many of its goals more directly by asking biographical and sociological questions, or looking critically at the language in prefaces, correspondence and the subject's texts other than translations. That is, by seeking its points of departure in translators rather than in translations (PYM 2009: 37).

In this spirit, this study seeks the motives driving the German translation of Boži duha not only in Patočka, his foreword to the German translation and other writing from the early 1970s, but also in the German academic, Frank Boldt (1942-2006), who founded and edited the Konstanz-based journal Postilla Bohemica, where the translation first appeared, alongside Patočka's essay and a foreword for German readers by Boldt. As Pym envisages, examining a partnership like that between Boldt and Patočka illuminates the traditionally uncontroversial dividing-line in translation studies between source and target culture. Drawing on the context of Arabic/Latin translation in twelfth-century Hispania, Pym writes:

[Gideon] Toury methodologically postulates that translators "operate first and foremost in the interest of the culture into which they are translating" [(TOURY 1995: 12)], but he presents little evidence to back the principle up. It seems equally likely that intercultural professionals also 
work for themselves, for their own material well-being, and perhaps even for some ideals that will outlive the decline of national sovereignties (PYM 2009: 35). ${ }^{3}$

Pym argues that agents of translation tend in fact to occupy what he terms an "interculture", the intersection of, for example, two or more national, linguistic or religious cultures, where individuals with shared professional, intellectual or philosophical interests congregate. He suggests that this "middle space has structures and dynamics that are something like those of the cultures themselves. Rather than a wholly accidental feature of history, this overlap would function as a cultural space with its own membership rites, norms of behaviour, ideologies" (PYM 2009: 39). As this study shows, this notion of an "interculture" neatly captures Patočka and Boldt's position in relation to Czech and German culture. Moreover, Pym's rejection of circumscribed understandings of source and target culture in favour of the more fluid and capacious notion of an "interculture" mirrors a fundamental philosophical position underpinning Patočka and Boldt’s translation.

\section{Durych's Boží duha and its reception}

Between the world wars, Durych, a devout Roman Catholic, had been a major prose writer and uncompromising, critical voice, vital to intellectual debate in First Republic Czechoslovakia. Judging by remarks in his private letters and the date on the final manuscript, he wrote Boži duha between about 1952 and 1955, by which time he had been completely cut out of contemporary literary and public life, and literary history, by Communist Party ideologues. According to Václav Durych, he hid the manuscript in a pile of coal in the cellar of his block of flats in Prague (VOJTÍŠKOVÁ-DURYCH 1995: 15), evidently aware of the controversial nature of its contents and presumably anxious not to create problems for himself or his family or harm the chances of re-publishing his earlier work, which began in 1956. The manuscript was submitted to the publisher Československý spisovatel by Durych's heirs in 1963, soon after his death, but was not approved for publication until May 1968, at the height of the "Prague Spring" cultural and political liberalization. The novel describes how the narrator, an old man, journeys from

3) Toury also claims that the choice of translations is driven by the target culture, "the observation that something is missing in the 'target culture' which should have been there and which, luckily, already exists elsewhere" (TOURY 1995: 27). Recent studies have suggested that this assertion is misplaced, especially in the case of less frequently translated literatures like Czech, where literary translation is often driven by the source culture's wish to be heard (VIMR 2020: 48-68) and indeed, as in the case of Boží duha, for reasons other than aesthetic considerations. 
his home to a devastated, abandoned landscape, where he encounters a young woman who gradually reveals to him the horrors that she has experienced there. The man in turn gradually feels a need to take responsibility for the woman's experiences and atone for them, and takes on the arduous task of burying a coffin containing the decomposing corpse of a woman and her baby. The woman helps him complete the task, and through this shared act of penance, they create the conditions for a new beginning in this land, as a new Adam and Eve.

Boží duha is a paradigmatic example of a novel that will be read differently by those who belong to the source culture and those who do not. When Jan Linka and I wrote our afterword to David Short's 2016 English translation, we imagined first that most English-speaking readers, unfamiliar with $C$ zech history, would associate it with the contemporaneous fashion for post-apocalyptic literature and cinema, typically set in unidentified or fictional locations at some point in the future (see CHITNIS-LINKA 2016: 239). By contrast, Antonín Měštan wrote: "today's Czech reader cannot read this work except [...] as a very pertinent reflection on the problem of the German population in the Bohemian lands in the twentieth century, and especially on its fate after May 1945", and predicted that "only when the problem of Czech-German relations between 1938 and 1946 ceases to interest the Czech and German public will the aesthetic aspect of this work take prime position" (MĚŠŤAN 1997: 187, 193). In this reading, the landscape is north Bohemia following the initially violent expulsion of over two million Bohemian Germans in 1945-46; the man is Czech, the woman German, and the novel a parable of reconciliation between the two peoples that had lived alongside one another in Bohemia for centuries. The question for anyone seeking to publish a translation of the novel is how far they consider it necessary to narrow the gap between $C$ zech and non-Czech readers.

As I have discussed elsewhere, the implied historical context was not mentioned by either internal readers for the publisher, Československý spisovatel, in 1963, 1964 and 1968, or reviewers in 1969 and 1970, after the novel was published (CHITNIS 2012: 44). It is most unlikely that none of these readers recognized it. The post-war political and media rhetoric asserting the collective guilt of the Germans and arguing that there was no alternative to the expulsions was quickly enshrined in imaginative literature, cinema and education. Most Czechs, like the narrator at the beginning of Boži duha, may therefore have believed that, with the liberation and restoration of Czechoslovakia, "all accounts had been settled [...] God's rainbow had shone over the land" (DURYCH 1991: 48). In 1967, however, the episode was cautiously reopened in a series 
of articles published by the historian Jan Křen (1930-2020), at the height of a period of unprecedented academic freedom in Communist Czechoslovakia, in which he eschews emotional nationalist rhetoric in favour of historiographical examination of sources. That same year, the historical novelist Vladimír Körner (1939) published his short novel Adelheid, which tentatively complicates the prevailing national narrative about the expulsions. Like Boži duha, it centres on an encounter between a Czech man and German woman in the post-war borderlands, but is much more explicitly grounded in the historical period and setting. A film of Adelheid, directed by František Vláčil (1924-1999), was released in 1969. It therefore seems more plausible that internal readers and reviewers avoided mentioning the subject for political reasons, because if Durych's novel is read in this light, it is not a Czech, but a German who is the victim, and the implicitly Czech narrator comes to realize that God's rainbow cannot shine until he recognizes his share of guilt and makes amends. It was Patočka and Boldt who first stated this interpretation explicitly in their 1975 German translation.

\section{History or Allegory? Boldt's and Patočka's forewords}

Both Boldt's preface for German readers and Patočka's accompanying essay precede Durych's text and thus establish the interpretative frame through which the translation is then read. The reader cannot but see the narrator as a Czech from the beginning, and the whole story is historicized. Patočka's essay was included, again as a foreword, in the 1988 French translation by Erika Abrams, and in the 1999 re-publication of the German translation, together with Boldt's preface. In 1991, a Czech translation of the essay was included in the second Czech edition, this time as an afterword, effectively giving Patočka the last word to the contemporary reader. The publication of this new edition coincided with the post-Communist rapprochement between Czechoslovakia and Germany, presaged by President Václav Havel's early, domestically highly controversial acknowledgement of and apologies for injustices committed by Czechs against Germans at the time of the expulsions. Jan Vladislav warned, however, that the novel was "neither a historical document, nor a political pamphlet” (VLADISLAV 1998: 47). Writing in July 1991, Václav Durych rejects the suggestion that the novel is about the deportations (DURYCH VÁCLAV 1991: 4). In a longer article published in 1995, he reiterates and develops these asser- 
tions, maintaining that "the transfer of the Germans left [...] Durych cold. He considered it still a phenomenon of war and made no particularly angry comments about their departure with their belongings on their backs [...] he was convinced of their collective guilt and no one would persuade him otherwise even today" (VOJTÍŠKOVÁ-DURYCH 1995: 15). Martin C. Putna, however, suggests that Václav Durych frequently confuses his own views with those of his father (PUTNA 2003: 88). Václav Durych's perspective found support in the psychotherapist Oldřich Č́lek's heated article from 1993, in which he attacks what he considers the "one-sided", "false" interpretation of Durych's novel: "It is seen merely as a criticism of the deportation of the Sudeten Germans, as though it had been written in the spirit of the motto: A tale of wicked Czechs and unlucky Germans... This is not, however, the true meaning of Boží duha. This kind of pseudo-interpretation is propagandistic, journalistic misuse of it" (ČÁLEK 1993: 13). Unlike Václav Durych, Ćálek separates Patočka's motives from those of contemporary intellectuals and politicians, suggesting that it is not only Jaroslav Durych, but also Patočka who is being misused.

Ćálek is not wrong when he writes: "We have to infer for ourselves that the novel relates to the subject of the Sudetenland" (ČÁLEK 1993: 13). In the novel, Durych names neither the historical period, nor the setting nor the protagonists. In an unpublished study that examines the various versions of the novel in progress, Jan Linka notes:

From the very genesis of the novel it is evident that Durych gradually erases traces of a real story and moves it to the level of fairy-tale timelessness. From the first text versions, moreover, apart from the collective pronouns "our" and "your", no other indication of individual or collective identity is given, unless we consider the heroine's red hair as a marker of German ethnicity (LINKA, undated: 11-12). ${ }^{4}$

Č́lek and Linka nevertheless understate the extent of the allusions to the historical time and setting, and accusations that Patočka is guilty of a wilful misreading of Durych are not sustained by the text. The narrator meets the woman after he takes refuge in what he thinks is an abandoned house, but which is actually her family home, then takes offence when she is scared by his presence. She says: "Don't get angry! I'm really frightened. After all, you can drive me out [vyhnat]..." (DURYCH 1991: 45). The Czechs have never officially accepted the term "expulsion"

4) My thanks to Jan Linka for allowing me to use his work for this article. 
(Vertreibung, in Czech vyhnánî), widely used by international historians, preferring instead the more legalistic "transfer" (in Czech odsun). The narrator's reply could even have a double-meaning, drawing attention to this debate: "Hm! Still just talking about me driving you out. [Stále jen vyhnat.] I'm starting to think that's what you really want me to do." Just before this, the woman tells the narrator: "I was born right here, alongside you [...] can't you tell by my accent?" (DURYCH 1991: 41). The possessive pronouns mentioned by Linka, which she uses to denote the perpetrators of violence against her, are readily decipherable: "our people" - logically the defeated Germans - hand her over to "them" - presumably liberating Soviet soldiers - who hold her for a week in her school, where she is repeatedly raped. She is then taken home by "your [the narrator's] lot" - the Czechs - who kill her mother as she tries to escape, then rape her as she stared into her dying mother's eyes before they killed her mentally handicapped aunt.

The risk of any additional framing of the novel for readers is that it will disrupt the delicate balance between the historical and universal in Durych's novel. Linka suggests it may be difficult for modern readers to appreciate this balance, arguing that "from the outset, the author deliberately constructs the typically two-dimensional message of realist narration in modern literature fourdimensionally, that is, with the further allegorical and mystical plane that we know from medieval and early modern Christian literature" (LINKA, undated: 10-11). Patočka's critics, however, easily overlook his own acknowledgement of this danger when he writes in his foreword:

The action depicted in Durych's novel has no wish to have anything in common with national or political matters in the narrow sense of the word. It is not decisive that here in the borderlands a Czech man and a woman of German origin meet at a time when the barrier had been lifted and the region is being resettled [...] It is important that here two penitents meet (PATOČKA 2004: 531).

Patočka nevertheless alters the fine balance in the novel between not only the historical and universal, but also the aesthetic and didactic, judging it a price worth paying.

\section{Intercultural smugglers}

Pym states that "to understand why translations happened, we have to look at the people involved” (PYM 1998: ix). Whether Patočka approached Boldt with 
a completed translation, or discussed the idea with him in advance, or indeed whether Boldt encouraged Patočka to do the translation, it seems essential to include Boldt as much as Patočka in any analysis of the venture. The Patočka archives in Prague and Vienna told me that they had no holdings relating to the translation. Ivan Chvatík from Prague noted that it had to be conducted with utmost secrecy, while Ludger Hagerdorn from Vienna thought the only possibility would be any papers left by Boldt, which do not appear to be held publicly. Hagedorn also noted that Patočka's letters to Krzysztof Michalski (1948-2013) from the same period make no mention of the Durych translation. ${ }^{5}$ Petr Blažek's volume of secret police documents relating to Patočka includes brief reference to Boldt, but not to any specific activity. We therefore do not know whether the translation was a joint enterprise, or whether one approached the other with the idea, or indeed how far Boldt was involved in the actual translation itself. The only direct information I have found about the background to the venture is Václav Durych's somewhat scornful claim that in the early 1970s "Patočka told [his fellow dissident academic Radim] Palouš about Boží duha and while reading him an extract from it, burst into tears" (DURYCH VÁCLAV 1991: 5). Given Michal Svatošs description of Boldt as "not only the publisher, creator, editor and 'brains [ideová hlava]' [behind Postilla Bohemica]" (SVATOŠ 2010: 9), we might conclude that to some extent Patočka led on inspiration and Boldt on realization, but this would be entirely speculative.

The partnership between Boldt and Patočka exposes the fallibility of neat distinctions between source and target culture. Boldt and Patočka might theoretically be considered representatives of, respectively, the target and the source culture on grounds of birth or first language, but this case study shows just how problematic it is to suggest that anyone speaks on behalf of a given culture. Both, moreover, had unusually deep relationships with the other culture. Patočka had had a long and close relationship with German culture and scholarship, dating back at least to the 1930s and his studies in Berlin and Freiburg, and often wrote and published in German. Between 1966 and 1970, Boldt studied at Prague University, where he encountered Patočka, and after the fall of Communism, he moved to the west Bohemian, former Sudetenland town of Cheb (Eger), later obtaining Czech citizenship. Their collaboration therefore places them more accurately in an "interculture", linked not ethnically nor linguistically, but by their professional and intellectual backgrounds, their worldviews and

5) My thanks to Ivan Chvatík and Ludger Hagerdorn for their detailed responses to my enquiries. 
above all their understanding of the history of Czechs and Germans in Bohemia, which put them at odds with prevailing opinion in both source and target culture. Patočka reflected this situation in the title of this 1975 Kacírské eseje o filozofii dějin (Heretical Essays in the Philosophy of History, PATOČKA 1996). In this context, the publication of Patočka's essay in Czech for Czech readers can scarcely be considered a case of a text intended only for readers in the target culture being misdirected back to readers in the source culture.

Boldt and Patočka perfectly fit Diana Roig-Sanz and Reine Meylaerts's apt characterization of certain cultural mediators as "smugglers", whose relationships with the authorities at both ends of their transactions tend to be idiosyncratic. They write:

They promote exchanges and often create their own norms, circuits, channels and forms [Boldt's Postilla Bohemica and Patočka's 'seminars in private flats' are quintessential examples of that]. In very relevant moments they felt a social responsibility towards a culture and a literature and they revolted against the trend, against the market (as far as this is possible), against the taste of the readers or against the prevailing aesthetics of the time (ROIG-SANZ - MEYLAERTS 2018: 3).

It is Boldt's foreword that most explicitly seeks to co-opt Durych into this shared "interculture" and "smuggler" identity. He notes how, at the height of Socialist Realism, Durych stays faithful to his "life-long Catholic Baroque poetics", producing a work whose realism "might fill the reader with revulsion and loathing" (BOLDT 1975: 15). This reaction had first been recorded in internal reader reports, which described the text as a "total loss of artistic good taste", not ostensibly because of its failure to conform to Socialist Realist precepts, but because of its grim images of sexual violence and physical decay and its apparent reduction of interethnic conflict to an old man's sexual fantasy. Most controversially from a Czech perspective, Boldt writes:

Perhaps the greatest achievement of Jaroslav Durych and the present novella may be that from the late vestige of loneliness and ostracism in which he had found himself for more than a decade, the words that suffuse us, in that down-to-earth nature of the inner language of his people, could have been taken from their perception (BOLDT 1975: 17-18). ${ }^{6}$

6) The crucial final clauses of this quotation are quite awkwardly expressed, perhaps reflecting their author's subconscious awareness of the boldness of his assessment. The original reads: "Die vielleicht grösste Leistung Jaroslav Durychs und seiner vorliegenden Novelle könnte es sein, dass aus dem späten Residuum von Einsamkeit und Verfemtheit, in dem Durych sich mehr als ein Jahrzehnt lang befand, Worte zu uns dringen, die in ihrer Volkstümlichkeit der inneren Sprache seines Volkes, seinem Empfinden abgelauscht sein mögen". 
Boldt's suggestion that the narrative of collective guilt, which placed all responsibility for what happened during the expulsions on the expelled Bohemian Germans, was not how Czechs really felt - that Durych had articulated some secret yearning for reconciliation - is not addressed to the Czech source culture, but seems intended to show a German audience that not all $\mathrm{Czechs}$ were intransigent and that there was hope of a different relationship in the future. Boži duha is thus vaguely cast as a Czech counterpart to the letter sent by Polish bishops to their German "brothers" in 1965, in which they both sought and offered forgiveness for crimes committed on both sides during and after the Second World War. Boldt had acted as a translator and interpreter for the West German Foreign Ministry in negotiations leading to the first post-war treaty between Czechoslovakia and West Germany in 1973, part of West German chancellor Willi Brandt's Neue Ostpolitik, his policy of rapprochement with the East. Měštan agrees that, in contradiction to the claims of Václav Durych, "[Jaroslav Durych] had reached [...] the conclusion that without effective regret on both the Czech and the German side, the problem of Czech-German relations was impossible to resolve" (MĚŠŤAN 1997: 188).

\section{Comenius and Czech history}

As we have seen, Patočka, in fact, doubts whether international relations were uppermost in Durych's mind. The novel seems to attract him more because of its resonance with his own thinking in the period about "great" and "small" history and the "open" and "closed" soul, oppositions that mirror Boldt's implicit contrasting of two Czech voices - one seeking renewed coexistence and one refusing it. Patočka published his essay "Komenský a otevřená duše” (Comenius and the open soul) in Czech in the periodical Křstanská revue in 1970, perhaps coincidentally a few months after its editor, Josef Smolík, published one of the few reviews of the first edition of Boži duha there. ${ }^{7}$ In the essay, Patočka describes the "closed soul" as "closed in on itself, from the outside a fenced-off continent, refusing anything foreign [...] No 'outside' [mimo] exists for it. That is

7) Patočka originally wrote the essay in German for publication in an anthology devoted to Comenius published the same year, and revised and augmented the Czech translation. Křestanská revue was a liberal Christian periodical founded in 1927 by the biologist and essayist, Emanuel Rádl (1873-1942), whom Patočka greatly admired, and the Protestant theologian, Josef Lukl Hromádka (1889-1969). Between the wars, intellectuals associated with Roman Catholicism like Durych showed little interest in publishing there, and Patočka's contributions to it place him intellectually very much at odds with contemporary conservative Roman Catholics. 
why it can and must come to terms with any problem using only its own powers and resources" (PATOČKA 1998: 337). At the beginning of Boži duha, the narrator abandons society for total solitude and self-sufficiency, and experiences his unexpected encounter with the woman as an unwelcome interruption, the impact of which he seeks to minimize. He believes there are no questions left to answer. She too has embraced isolation, imprisoned in the memories of her traumata, which she initially is unwilling to disclose. Patočka argues that the "closed soul" exploits Reason to justify its perception of the world. By contrast, "for Comenius, Reason [...], in order to see things as they are, must first learn to understand that its tendency to measure things by themselves can only achieve correct results when the human being opens himself up and subordinates the whole of his soul to something entirely other and higher" (PATOČKA 1998: 339). Patočka is able to separate Comenius's subsequent "theological and metaphysical speculation" from the notion of the "open soul" and its fundamental act, "to devote itself intentionally to things, yield itself to the benefit of things, people and God, and find itself in that surrender of itself" (PATOČKA 1998: 339). Through their initially halting, fractious and often painful interaction, both "closed souls" in Boži duha open themselves to another, and in prioritizing the healing of the other, redeem themselves and the world.

In "Komenský a otevřená duše", Patočka argues that while the "closed soul" has become commonplace in the modern period, in late medieval Europe, the dominant concept was the "Christian soul" - for him a paradigmatic example of the "open soul" - "set before something beyond its powers" (PATOČKA 1998: 338). This change over time corresponds to the account of Europe's decline that he developed in the same period in the essays like "Duchovní základy života v naší době" ("The spiritual foundations of life in our times", PATOČKA 1999, also published in Křstanská revue in 1970), and in Heretical Essays in the Philosophy of History. In this account, Europe, understood as a spiritual ideal of humanity rooted in ancient Greek philosophy and its reverberations through to late medieval Christianity, gradually surrenders universality in favour of fragmentation. In a long essay, "Was sind die Tschechen?" (What are the Czechs?), written in German between the late 1960s and 1973 for a West German friend, Hildegard Ballauff, he writes: "Medieval universality was built over all linguistic, cultural and regional particularisms as something higher, which connected and arched over them [...] When the canopy of medieval Christianity was lost, what it overarched remained: peculiarities, nationality, diffuse languages and traditions" (PATOČKA 2006: 303). We can see here what he believed he shared 
with Durych, whose writing consistently calls on "lost" human beings and "lost" Czechs to return to his understanding of that former universality and unity, the Catholic Church.

In this essay, Patočka characterizes the shift from the medieval to the modern in terms of "great" and "small" histories, and maps the history of the Czechs onto his account. Contrasting the late medieval period with early nineteenth century, he writes: "while great [Czechness] could think about the problems of Europe, realize itself and expend its energies in her services and her conflicts, small Czechness from the start, because there was no other way, thought only about itself, about preserving its existence, which it identified ever more exclusively with language" (PATOČKA 2006: 299). Though he does not discuss the post-war expulsions, the essay becomes a fierce criticism of President Edvard Beneš and his consistent choice of "smallness" over "greatness" in his responses to the challenges of the 1930s, and it is clear that his leading role in supporting and justifying the expulsions falls into the same category. Patočka admires in Boži duha its assertion of pre-modern Christian universalism, and sees the characters' story as the shedding of "smallness", of shallow, narrow nationalisms, and redemption understood as the rediscovered potential for "greatness" in this life.

\section{Patočka and Durych}

Alongside these broader philosophical resonances, in his foreword to Boží duha, Patočka nevertheless enlists Durych and his novel in an analysis of CzechGerman relations that arises from his account of history and radically contradicts the competing narratives of victimhood preferred at the time by both Czechs and Bohemian Germans and their descendants. In the foreword to Boží duha, Patočka writes of the Second World War and its aftermath:

The torrents of history flushed out the problems of spirituality raised by the First Republic and with them also the thousand years of life lived together by Czechs and Germans in one land - that unique history that deeply shaped both national tribes. It is a sequence of events that in their tragic nature fall into step with Europe's departure from the summit of world history, one of the most terrible theatres on the world stage, born of deep national hatred nurtured for centuries, of crafty calculation, of vengeful plans old and new, from foolishness bordering on mental derangement, coupled with unparalleled moral shamelessness on both sides. The sheer 
burden of guilt that we have thus placed on ourselves and that we will have to bear through our current and apparently also future history, found in this novel its spokesman, its poet (PATOČKA 2004: 529). 8

The first-person plural used by Patočka is not the Czechs, but both Czechs and Germans. This passage shows that his foreword, unlike Boldt's, was addressed as much to Czech as to German readers. The editors of Patočka's collected works note that he amended the original manuscript of "Was sind die Tschechen?", adding "den Tschechen" to the subtitle so that it reads: "Ein Versuch, sich den Tschechen und Nicht-Tschechen verständlich zu machen" (An attempt to make myself comprehensible to Czechs and non-Czechs) (PALEK-CHVATÍK, 2006: 476). In this period at least, Patočka repeatedly expresses his sense of speaking from "outside" ("mimo", as he writes in "Komenský a otevřená duše"), in effect from an "interculture" to all nationally defined cultures. The objections of commentators like Václav Durych and Ćálek to the co-opting of Durych into this 'heretical' interpretation of recent Czech history are not sustained by an honest reading of Boži duha. Indeed, the focus and emphasis of Durych's text is on Czech readers, asking them to reconsider their understanding of recent history, just as the implicitly Czech narrator does.

A more persuasive, though ultimately unresolvable criticism of Patočka's reading of Durych in his foreword is his implication that the Durych who wrote Boži duha would have been more willing than inter-war Durych to acknowledge and explore what he shared with intellectually kindred spirits from other faiths and none. Č́lek attributes Patočka's involvement in the translation of Boží duha to "'the spirit of his philosophy of the 'solidarity of the shocked" (ČÁLEK 1993: 15). In this context, the venture may be understood as an attempt to bring Durych into an alliance with other intellectuals who share his concern about declining spirituality in Europe, in Pym's terms, to expand the "interculture" shared by Patočka and Boldt. In his foreword, Patočka argues that during the First Republic Durych was so blinded by his hostility to secularized modernity

8) The perception that both sides behaved equally badly towards each other underpins Boldt's analysis of Bohemian history in his own writing, including that addressed to Czech readers, like the 1995 edited volume Velké dĕjiny, maly národ, an allusion to Patočka's account of Czech history. It begins with an essay by the German historian, Immanuel Geiss, who writes: "The double catastrophe of the years 1938/45 was the final result of an escalating process, in which one side reacted to the other more harshly: 1918 and its consequences were harsher than German actions in the Danube monarchy before 1918, 1938 and its consequences were harsher than Czech actions and reactions in the preceding twenty years. 1945 was harsher than the German evil committed against Czechs since 1938" (GEISS 1995: 19). This controversially "even-handed" view also underpins Boldt's posthumously published essay on Czech-German coexistence, Cheb - město evropských dějin (Cheb - the city of European history, BOLDT 2010). 
that he did not see the possibility of such alliances, a failure manifested above all in his loathing of Czechoslovakia's first president, Tomáš Masaryk, whom Patočka, in "Was sind die Tschechen?" and elsewhere, so admires. He writes:

Our modern life did not allow itself to be pierced by a ray of light from the absolute, except for a few exceptions, of whom Masaryk was perhaps the most important. But is it not the case for Masaryk himself, as for Durych, that the correct diagnosis is accompanied essentially by a proposal for extreme therapy? Was not the liberation of Catholicism through renewed religious thought and life a path that was perhaps closer to reality? A path that would be much closer to the common people and their life and that might perhaps also extend to educated people and, indeed, awaken enthusiasm in them? Whatever the case may be, the guilt of intransigent Catholicism, or that which wanted to be intransigent, perhaps lies precisely in the fact that it made that path impossible (PATOČKA 2004: 528-529).

Patočka suggests that in Boží duha, Durych appears to repent this intransigence, and moves from a vertical preoccupation with the human being's relationship with God to a more horizontal focus on human beings' relationships with one another. In effect, as in his analysis of Comenius' notion of the "open soul" in "Komenský a otevřená duše”, Patočka finds it easier in Boží duha than in Durych's earlier work to separate his vision of how to live in this world, on which they are broadly agreed, from his notions of the next, where their views may differ. ${ }^{9}$

There is critical consensus, based on Durych's post-war writing and private letters, that he emerged from the experience of the Second World War and the Communist takeover humbler and gentler. His 1929 novel Bloudění also depicts the gradual coming together of a man and a woman against the backdrop of terrible conflict, in this case the Thirty Years War. As in Boží duha, the main male character, Jiří, may be understood to represent the Czechs; like the narrator in Boži duha, he is foolish, clumsy, abrupt and slow on the uptake, but in Boží duha this ironic characterization is implicitly self-directed. In Blouděni, the leading female character, Andělka (Angela), is more heavenly than terrestrial, the embodiment of light and warmth and a metaphor for the Roman Catholic Church, constantly

9) The contrast between Durych and secular writers that Patočka seeks to elide is evident from a comparison of the treatment of the motif of a new Eden and Adam and Eve at the end of Boži duha with the ending of the play R.U.R. (Rossum's Universal Robots, 1921) by Karel Čapek (1890-1938), a writer intellectually and personally close to Masaryk, whom Durych subjected to repeated criticism in the inter-war press. Boži duha is marked by optimism; paradise is restored through repentance, atonement and love between two people who were at war. R.U.R., however, ends much more pessimistically. Eden is only restored following the destruction of humankind; it is not earned, but comes about thanks to an ill-defined life-force. 
present when Jiři is in need, waiting for him to realize that she is the one. By contrast, in Boží duha, the female character is a metaphor of traumatized humanity, and light and warmth - the rainbow - are generated by the healing and joining of two human beings in mutual understanding and love. To conclude, however, that Durych had therefore become more ecumenical in this thinking and might even have had more time for Masaryk is highly speculative, and would undoubtedly be seen as a step too far by those most familiar with and sympathetic to his frequently expressed rejection of Masarykian secularism and profound attachment to Roman Catholicism. Indeed, Boži duha is more easily read not as a text about Durych coming round to a broader conception of spirituality that embraces Masaryk and Patočka, but as an expression of hope that post-war recognition of the harm and devastation that Europeans have visited on one another might act to return them to the teachings of the universal church.

\section{Conclusion}

Boldt and Patočka's Boži duha venture arises from and belongs to a specific historical and intellectual context. As we can see from the pessimistic tone of Patočka's other writing in the early 1970s, the period after the 1968 Soviet-led military intervention in Czechoslovakia was a time of great despair for intellectuals throughout Europe like Patočka, and their heirs, like Boldt, who in the 1960s had glimpsed the possibility of Europe-wide reconciliation and renewal based on ideals of democracy, solidarity and empathy that they believed were defining for the continent. The translation of Boži duha exemplifies their efforts to find ways to be active, to keep a flame burning. Like Durych, Patočka and Boldt saw the entrenched positions of Czechs and Germans with regard to the war and its immediate aftermath as a metaphor for the stagnant division and alienation imprisoning and diminishing human minds and lives in Central Europe and beyond. Through their translation, they sought to animate a new conversation about that specific history, at a time when the Czech-German relationship was increasingly unusual in its failure to resolve matters enduring from the Second World War. Though they failed in 1975, Boldt and Patočka would surely have seen the debate in the 1990s sparked by their reading of Durych as a continuation of the conflicts between "great" and "small" Czechness, "closed" and "open" souls, and conservative nationalism and Roman Catholicism and liberal cosmopolitanism, ecumenism and secularism. Paradoxically, their German translation paved 
the way for Božíduha's sustained reception in Czech after 1991, and undoubtedly helped ensure that, in the twenty-first century, the novel, still the most radical examination of the expulsions in Czech literature, has become a core text in the school curriculum and the subject of adaptations for television and the stage.

The real difficulty with Patočka's essay lies not in its interpretation of Boží duha, but in the fact that the frame it creates came, after Patočka's death, to serve not just as a possible reading, but as an apparently necessary explanation of Durych's novel, which for a time seemed inseparable from publications of the work in translation or in Czech. The essay may have been included in French and German editions to make the novel not only more accessible, but also more attractive to readers familiar with Patočka's name, especially given his association with the Charter 77 movement. Its inclusion in the second Czech edition, however, as Ćalek suggests, seemed like a weaponizing of Durych's novel in the service of contemporary political fashion. Citing Paul Ricoeur, a fellow disciple of Edmund Husserl (1859-1938) and admirer of Patočka, Bubeníček argues that with his essay, Patočka imitates what writers themselves seek to do: "disrupt through their artistic work 'the conventional, hypocritical image of themselves that decent people attempt to create"' (BUBENÍČEK 2007: 280), but it diminishes Durych's achievement if we suggest that the novel needs Patočka's essay alongside it to achieve this effect. Despite Patočka's attempts to acknowledge and replicate Durych's use of a particular tragic episode to remind human beings of another way of apprehending the world and relating to one another, there is a need, for literary, not political reasons, to return to Czech and international readers the freedom to decide where the balance between the historical and universal and the aesthetic and didactic lies in Durych's Baroque allegory. The publishers' decision not to include the essay in the 2016 English translation of Boži duha reflects that it has long been time for Durych's novel and Patočka's essay to find a new form of co-existence. ${ }^{10}$

\title{
PRIMARY SOURCES:
}

\author{
DURYCH, Jaroslav
}

1991 [1969] Boži duha (Prague: Academia)

10) I have not been able to check whether Patočka's essay was included in the Hungarian translation by Klára Körtvélyessy published in Bratislava in 2002 or the Spanish translation by Helena Voldan published in Buenos Aires in 2006, but unlike earlier French and German translations, library catalogue entries make no mention of it. 
PATOČKA, Jan

1996 [1990] Heretical Essays in the Philosophy of History, trans. Erazim Kohák, ed. James Dodd (Chicago and La Salle: Open Court)

1998 [1970] "Komenský a otevřená duše", in Jan Patočka: Komeniologické studie II. Sebrané spisy Jana Patočky. Vol. 10, ed. Věra Schifferová (Prague: Oikoymenh - Filosofia), pp. 223-231

1999 [1970] “Duchovní základy života v naší době”, in Jan Patočka: Péče o duši II. Sebrané spisy Jana Patočky. Vol. 2, eds. Ivan Chvatík, Pavel Kouba (Prague: Oikoymenh), pp. 9-28

2004 [1975] "Předmluva k Boží duze Jaroslava Durycha", in Jan Patočka: Umění a čas I. Sebrané spisy Jana Patočky. Vol. 4., eds. Daniel Vojtěch, Ivan Chvatík (Prague: Oikoymenh - Filosofia), pp. 526-535

2006 [1985] “Co jsou Češi?”, trans. Vladimír Jochmann, Jan Sokol, in Jan Patočka: Češi II. Sebrané spisy Jana Patočky. Vol. 13, eds. Karel Palek, Ivan Chvatík (Prague: Oikoymenh - Filosofia), pp. 253-324

\section{SECONDARY SOURCES:}

BLAŽEK, Petr

2017 “Kéž je to všecko ku prospěchu obce!": Jan Patočka v dokumentech Státní bezpečnosti (Prague: Academia)

\section{BOLDT, Frank}

1975 “Vorrede für den Deutschen Leser”, Postilla Bohemica 4, no. 11-12, pp. 15-18

2010 Cheb - město evropských dějin. Esej o česko-německé koexistenci (Prague: Litomyšl - Paseka)

\section{BUBENÍČEK, Petr}

2007 “K Patočkově interpretaci Durychovy novely Boží duha”, Ivo Navrátil - Tomáš Hermann (eds.): Jan Patočka, české dějiny a Evropa (Semily: Státní okresní archiv), pp. 271-281

ČÁLEK, Oldřich

1993 “Zápas o Boží duhu”, Tvar 4, no. 39-40, p. 13

CHITNIS, Rajendra

2012 “Moral Limits': The Expression and Suppression of Guilt in Czech Post-War Writing About the Borderlands", Central Europe 10, no. 1, pp. 18-54.

CHITNIS, Rajendra - LINKA, Jan

2016 "Afterword: Ira et iris seu littera gesta docet", in Jaroslav Durych: God's Rainbow, translated by David Short (Prague: Karolinum), pp. 239-249

DURYCH, Václav

1991 “Oh money, money”, Moravské noviny, July 18 ${ }^{\text {th }}$, pp. 4-5

\section{GEISS, Immanuel}

1995 “Německý pohled na české země: Češi a jejich dějiny viděné z Německa”, in Frank Boldt (ed.): Velké dějiny, malý národ: O dnešní české státnosti a o současném odkazu velkých dějin zemí české koruny a československé republiky (Prague: Český spisovatel, Evropské Comenium), pp. 7-21 
KASTEN, Tilman

2014 "Pavel Eisner a Bloudění Jaroslava Durycha: literární transfer, tvorba kánonu a identita”, Česká literatura 62, no. 6, pp. 745-783

LINKA, Jan

Undated "Fašista a formalista píše Boží duhu: Rozpor veřejné podobizny a vnitřního světa Jaroslava Durycha" (typescript of unpublished article), $14 \mathrm{pp}$.

MĚŠŤAN, Antonín

1997 “K problematice Boží duhy”, in Jan Dvořák (ed.): Bloudění časem a prostorem. Jaroslav Durych známý i neznámý (Hradec Králové: Gaudeamus), pp. 187-193

PALEK, Karel - CHVATÍK, Ivan

2006 “Ediční komentář", in Jan Patočka: Češi II. Sebrané spisy Jana Patočky. Vol. 13, eds. Karel Palek and Ivan Chvatík (Prague: Oikoymenh - Filosofia), pp. 421-481

PUTNA, Martin C.

2003 Jaroslav Durych (Prague: Torst)

PYM, Anthony

1998 Method in Translation History (Manchester: St. Jerome Publishing)

2009 "Humanizing Translation History", Hermes - Journal of Language and Communication Studies, 42, pp. 23-48

ROIG-SANZ, Diana - MEYLAERTS, Reine (eds.)

2018 Literary Translation and Cultural Mediators in 'Peripheral' Cultures: Customs Officers or Smugglers? (Basingstoke: Palgrave Macmillan)

SVATOŠ, Michal

2010 "Slovo o autorovi", in Frank Boldt: Cheb - město evropských dějin. Esej o česko-německé koexistenci (Prague: Litomyšl - Paseka), pp. 5-12

TOURY, Gideon

1995 Descriptive Translation Studies - and beyond (Amsterdam, Philadelphia: John Benjamins)

VIMR, Ondřej

2020 “Supply-driven Translation: Compensating for Lack of Demand”, in Rajendra Chitnis, Jakob Stougaard-Nielsen, Rhian Atkin and Zoran Milutinović (eds.): Translating the Literatures of Small European Nations (Liverpool: Liverpool University Press), pp. 48-68

VLADISLAV, Jan

1998 “Z Pařižského deníku”, Proglas 9, no. 5-6, pp. 47-51 
VOJTÍŠKOVÁ, Marie - DURYCH, Václav

1995 “Jaroslav Durych a Lužické hory”, Českolipsko literárni 12, pp. 7-43

Dr. Rajendra Chitnis, rajendra.chitnis@mod-langs.ox.ac.uk, Faculty of Medieval and 